


Working Paper No. 696

\title{
Time Use of Mothers and Fathers in Hard Times and Better Times: The US Business Cycle of 2003-10*
}

by

\section{Gunseli Berik}

University of Utah

\author{
Ebru Kongar \\ Dickinson College
}

November 2011

Revised on November 15

\footnotetext{
* A revised version of this working paper was published in Feminist Economics 19(3), 2013, and may be accessed at http://dx.doi.org/10.1080/13545701.2013.798425
}

The Levy Economics Institute Working Paper Collection presents research in progress by Levy Institute scholars and conference participants. The purpose of the series is to disseminate ideas to and elicit comments from academics and professionals.

Levy Economics Institute of Bard College, founded in 1986, is a nonprofit, nonpartisan, independently funded research organization devoted to public service. Through scholarship and economic research it generates viable, effective public policy responses to important economic problems that profoundly affect the quality of life in the United States and abroad.

Levy Economics Institute P.O. Box 5000 Annandale-on-Hudson, NY 12504-5000 http://www.levyinstitute.org 


\begin{abstract}
The US economic crisis and recession of 2007-09 accelerated the convergence of women's and men's employment rates as men experienced disproportionate job losses and women's entry into the labor force gathered pace. Using the American Time Use Survey (ATUS) data for 2003-10, this study examines whether the narrowing gap in paid work over this period was mirrored in unpaid work, personal care, and leisure time. We find that the gender gap in unpaid work followed a U-pattern, narrowing during the recession but widening afterward. Through segregation analysis, we trace this U-pattern to the slow erosion of gender segregation in housework and, through a standard decomposition analysis of time use by employment status, show that this pattern was mainly driven by movement toward gender-equitable unpaid hours of women and men with the same employment status. In addition, gender inequality in leisure time increased over the business cycle.
\end{abstract}

Keywords: Economics of Gender; Unemployment; Time Use; Economic Crises

JEL Classifications: D13, J16, J22, J64 


\section{INTRODUCTION}

In December 2007, the US economy entered the longest and the deepest economic downturn since the Great Depression. Between 2007 and 2009, the average unemployment rate doubled, increasing from 4.6 percent in 2007 to 9.3 percent in 2009. Job losses came disproportionately for men as the male-dominated manufacturing and construction sectors were hit harder.

Growing evidence suggests that, in the face of high male unemployment, women entered the labor force as added workers to supplement family income (Şahin, Song, and Hobijn 2010). Women's share of paid employment, which had been hovering around 45 percent since 1978, reached the 50 percent threshold for the first time in US history in 2009 (IWPR 2011a). ${ }^{1}$ The "Great Recession" thus provided the context for acceleration of the trends that have been under way since the 1950s. ${ }^{2}$ This study examines whether the recession also occasioned convergence in gender disparity in unpaid work burden and overall progress toward gender equity in workloads, leisure time, and personal care hours.

The long-term trend in unpaid childcare and housework in the US has been one of gender convergence. A number of studies found that, between 1965 and 2003, the gender difference in paid work hours narrowed as men spent more time on unpaid work and women spent less (Bianchi, Robinson, and Milkie 2006; Blau and Kahn 2005). However, progress in gender equality in unpaid work was much slower compared to paid work, and as of the early 2000s, women continued to take on a disproportionate share of unpaid work (Bianchi, Robinson, and Milkie 2006; Sayer 2005).

In this study we examine the extent to which the narrowing of gender disparity in paid work during the 2007-09 recession was accompanied by gender convergence in unpaid work, leisure, and personal care time. The recession's impact on time use has not yet been comprehensively examined. More generally, our knowledge of gendered outcomes of the latest business cycle in time use (unpaid work, leisure, and personal care) is very limited. Only a few

\footnotetext{
${ }^{1}$ According to seasonally adjusted Current Employment Statistics data, the share of women in payrolls peaked in October 2009 at 49.96 percent (BLS 2010). The seasonally unadjusted data show that women's share in payrolls reached 50.02 percent in November 2009 and peaked in January 2010 at 50.29 percent.

${ }^{2}$ Notably, between 1970 and 2007, US women's labor force participation rate increased from 43.3 percent to 59.1 percent, and the proportion of men in the labor force decreased slightly, from 80 percent to 73 percent (Lee and Mather 2008). The trend in women's labor force participation rate held for married women and those with young children. Between 1970 and 2007, labor force participation of married women increased from 40.8 percent to 61 percent and that for married mothers (with children under 18 years) rose from 39.7 percent in 1970 to 69.3 percent in 2007 (Macunovich 2010).
} 
studies have analyzed intra-household time use questions in the context of either the Great Recession or the 2003-10 business cycle. The focus of these studies has been on the effect of unemployment on family time (Morrill and Pabilonia 2011) and the changes in time use ushered by declining market (paid work) hours of men (Aguiar, Hurst, and Karabarbounis 2011). A comprehensive analysis of the effect of the 2003-10 cycle on the trends under way in unpaid work hours - via the cycle's effect on paid work hours — would provide new insights on recent progress toward greater fairness in sharing of unpaid work burden and changes in gendered well-being.

Our empirical analysis relies on individual-level data from the 2003-10 American Time Use Survey (ATUS) and the methodology recommended by the Bureau of Labor Statistics (BLS) for multi-year analysis of changes in time use (US Census Bureau 2006). The sample consists of women and men who live in the same household with their spouse and at least one child and hence we refer to women and men interchangeably as mothers and fathers. We undertake three complementary analyses: First, we conduct analysis of variance (ANOVA) and post-hoc analysis to determine the variations in time use by gender over the 2003-10 business cycle. This analysis shows that the gender convergence in paid work was accompanied by a convergence of unpaid work hours during the recession period followed by a divergence in the postrecession period leading to an overall rise in work hours of women vis-à-vis men. Gender inequality in leisure hours widened over the business cycle.

Second, we examine the extent of gender segregation in detailed housework and childcare activities in order to gain insights into the source of the U-shaped pattern in unpaid work. This analysis shows that while gender segregation in housework was greater than in childcare, both activities became less segregated during the recession, but segregation in housework picked up again in the postrecession period. Thus, this study highlights both the resistance of gender division in housework to change and the slow change that is underway in childcare.

Third, through a standard decomposition analysis we examine the time use patterns by employment status of women and men-full-time employed, part-time employed, unemployed, not in the labor force. This analysis shows that the narrowing gender gap in unpaid labor during the Great Recession and the widening gap in its aftermath were driven largely by the withinemployment status group changes. Changes in employment status contributed to more equitable 
sharing of unpaid labor over the business cycle (through changes in women's employment status during the recession and changes in men's employment status in the aftermath).

\section{BACKGROUND}

Macroeconomic theory has long predicted household production to increase during recessions as households substitute home-produced goods and services for market purchases (Benhabib, Rogerson, and Wright 1991; Greenwood and Hercowitz 1991). Only recently has it been possible to empirically test the relationship between unpaid household production and recessions for the US as time use data became available over a business cycle. American Time Use Survey (ATUS) data, available since 2003, have enabled an emerging literature on the relationship between unemployment, and lately the Great Recession, and unpaid work hours in the US economy.

Focusing on the 2003-06 period, the first phase of the latest business cycle, Michael Burda and Daniel S. Hamermesh (2010) show that the metropolitan area unemployment rates in the US were positively correlated with unpaid work hours while unemployment, measured at the individual level, caused a disproportionate increase in leisure time rather than home production. ${ }^{3}$ Mark Aguiar, Erik Hurst, and Loukas Karabarbounis (2011) find that a considerable share of the decline in market work hours during the Great Recession (35 percent of the foregone market hours) was allocated to home production. The focus of these studies has been changes in household production at the aggregate level with no attention to gender-differentiated effects of unemployment.

An equally limited number of gender-aware studies have examined the changes in time use during the Great Recession. Based on 2008 ATUS data Heidi Hartmann, Ashley English, and Jeffrey Hayes (2010) have identified a gender asymmetry in the recession's impact on caregiving time: while individual unemployment doubled women's caregiving time, it increased men's caregiving time only slightly. Unemployed men spent twice as much time on housework as employed men but barely increased their caregiving time. Examining the variation in the time parents spent with their children with state unemployment rates over the 2003-09 period, Morrill and Pabilonia (2011) have found that mothers' time with children was invariant to state

\footnotetext{
${ }^{3}$ The finding that unpaid work hours increase with unemployment rates in the US also holds for other industrialized economies, namely, Germany, Italy, Australia, and Korea (Lee, Kawaguchi, and Hamermesh 2011).
} 
unemployment rates. However, at higher unemployment rates the time mothers spent on educational (enriching) childcare activities such as socializing and attending cultural events with children decreased (Morrill and Pabilonia 2011). ${ }^{4}$ As the state unemployment rates increased, fathers spent more time in all childcare activities, including the enriching ones. ${ }^{5}$

These findings suggest that the patterns during the cycle were consistent with those identified in gender-differentiated microeconomic crosssection and trend analyses for the US (Bianchi et al. 2000; Bianchi, Robinson, and Milkie 2006). Cross-sectional analyses of variation in time use by individual and household characteristics have found that in the US employed mothers and fathers spend less time on childcare and housework compared to their counterparts who are not employed (Bianchi, Wight, and Raley 2005; Hartmann, English, and Hayes 2010). Both employed and unemployed women spend more time on housework and childcare than their male counterparts (Hartmann, English, and Hayes 2010).

Trend data also show that in the US as mothers increased paid work since 1965 they reduced their time in housework but not childcare and fathers increased their time in the home, initially in housework and gradually in childcare (Bianchi, Robinson, and Milkie 2006). Time diary data for the 1965-2000 period show that the difference between mothers' and fathers' paid work hours narrowed by more than 20 hours per week, primarily due to an increase in mothers' paid work hours (by 16 hours) (Bianchi et al. 2000). Studies that examined how mothers "financed" this 16 hour increase in their workload found that as mothers increased their paid work hours, they had considerably less leisure time and spent less time on personal care and housework (Bianchi et al. 2000; Howie et al. 2006; Sandberg and Hofferth 2001).

Mothers seem to have protected their childcare time, even increasing it after 1985, a result that is also observed in other European countries (Gauthier, Smeeding, and Furstenberg 2004). Fathers in the US increased housework hours between 1965 and 1985. The convergence

\footnotetext{
${ }^{4}$ Morill and Pabilonia (2011) characterize enriching childcare activities as educational time with children, such as help with homework and reading to children, as well as time playing and talking with any of their children. For children aged two and older, they also include socializing and attending events with children (Pabilonia and Song 2011; Stewart 2010). For a complete list of activities, see Morrill and Pabilonia (2011).

${ }^{5}$ While the institutional context may be very different, studies on the Global South show that recessions increase women's share of unpaid household labor. One mechanism through which this happens is substitution of home production for previously purchased market goods and services. During the Asian financial crisis in several countries women's total hours increased in absolute terms as well, as women took up paid work or additional hours of employment to make up for decline in their spouse's unemployment or fewer hours of employment (Lim 2000; Singh and Zammit 2000). Moreover, cross-section analyses of time use during nonrecessionary periods in China and Ethiopia show that convergence in women's and men's paid work hours was not paralleled in unpaid work (MacPhail and Dong 2007; Mabsout and van Staveren 2010).
} 
in mothers' and fathers' housework hours slowed down in the post-1985 period, and was driven solely by a slight decline in mothers' housework hours (Blau and Kahn 2005). Over the same period, the convergence in childcare hours also stalled, as fathers and mothers increased their childcare hours by about the same amount. After 1995, the convergence in paid work hours also slowed down, but not as much as unpaid work hours.

Slower convergence in unpaid work compared to paid work has been traced to persistence of gender-inequitable norms with respect to childcare and housework (Rones, Ilg, and Gardner 1997; Sayer, Cohen, and Casper 2004.). While it became more acceptable for women to adopt the traditionally masculine behavior of breadwinning, men have been slow to adopt the feminine behavior of doing unpaid work, possibly because of its devaluation (Coltrane 2000; Risman 1998).

Surveys of attitudes also suggest that the increase in fathers' childcare time since the early 1990s has been consistent with men's greater willingness to be more involved fathers (Boushey and O'Leary 2009; Coltrane 2000). There is some evidence that young men are taking jobs that offer flexibility and shorter work hours so that they can meet family responsibilities (Carr 2002). However, the attitudes toward housework remain more in conformity with traditional gender division of labor. A recent survey showed that 85 percent of women, but only 67 percent of men, agree that in households where women have jobs, women take on more responsibilities for the home and family than their male partners (Boushey and O'Leary 2009).

Similarly, the finding that mothers protected their childcare time when their paid work hours increased is traced to the meaning of motherhood in the US as always being there for your children (Hays 1996; Blair-Loy 2003). The same recent survey showed that these genderasymmetric norms regarding motherhood persist in today's economy: 54 percent of men and 44 percent of women agree that "it is harder for a mother who works outside the home to establish as warm and secure a relationship with her children as a mother who does not work outside the home" (Boushey and O'Leary 2009, p. 406).

A number of studies have also argued that further progress toward gender equality in unpaid labor hours is unlikely without relaxation of institutional constraints, such as moving away from the "male" model of employment (with long work weeks) and having childcare centers open for longer hours (Boushey and O'Leary 2009; Jacobs and Gerson 2004; Williams 2000). Thus, underlying the linkages between changes in paid and unpaid work hours of women and men is the interplay between labor markets, gender norms, and the institutional and 
historical setting. While this study does not investigate the factors that explain the gender differences in time use outcomes, it examines how these factors are reflected in the aggregate patterns of time use.

Based on the macroeconomic and microeconomic literatures we expect an inverse relationship between participation in paid work and engaging in unpaid household activities. Thus, the increase in women's paid work hours and decline in men's paid work hours should be reflected in corresponding shifts in women's and men's unpaid work hours. While we expect the convergence in paid work hours of women and men during the Great Recession to be coupled with convergence in unpaid work hours, there is no reason to expect changes in paid work hours of individuals to be matched exactly by the changes in their unpaid work hours, given the rigidities in gender norms. Just as childcare hours of employed women may not be responsive to their entry into the labor force or increased hours at paid work, housework hours of men may not be responsive to the decline in their labor market hours or employment status. As a result, leisure or personal care hours are also likely to be affected by the employment shifts ushered by the recession or the period of slow recovery. Taken together, these time use indicators will help identify gender differences in the well-being impacts of the Great Recession.

After the official end of the recession in July 2009, we expect the changes in unpaid work hours to have continued at a slower rate. Especially after January 2010, when men gained jobs while women's employment was flat, the paid employment gender gap began to widen (Kochhar 2011; IWPR 2011b), signaling a return to the paid work patterns of the prerecession years. Should the time use data reflect these trends, we expect a slowdown in the convergence of women's and men's unpaid work hours in the recovery period compared to the Great Recession.

\section{EMPIRICAL ANALYSIS}

\section{Data}

Our sample comprises 25,430 ATUS time diary respondents between the ages of 18 and 65 who resided in the same household with their spouse and at least one child. We exclude women and men who were in the armed forces, students, self-employed, or employed without pay. The sample includes 13,439 women and 11,991 men. Appendix Table 1 reports the individual and household characteristics of women and men in our sample. 
Following the recent US empirical literature on time use, we distinguish among four alternative uses of time: (paid) market work, unpaid work (housework, childcare, adult care, shopping), leisure and sports activities, and personal care, which is mainly sleep (Connelly and Kimmel 2008; Kimmel and Connelly 2007). We aggregate detailed activities, reported according to the standard BLS categories, into these four groups. We keep childcare and housework as separate categories of work, assuming that market and home production of goods and services are perfect substitutes, except in the case of childcare. Unlike home production of goods and services, parental childcare is assumed to yield additional utility to parents.

Housework encompasses all types of housework, such as interior and exterior cleaning, laundry, sewing, repairing textiles, and shopping. Childcare comprises primary care activities of providing physical care for children; reading to, playing with, and looking after children; doing arts and crafts, playing sports, talking with, listening to children; organizing, planning, attending children's events; and picking up or dropping off children. ${ }^{6}$ Adult care consists of providing physical and medical care for adults, obtaining medical and care services for them, and waiting associated with these activities. Personal care comprises of mostly sleep, but also includes selfcare activities. Leisure and sports activities, hereafter "leisure," encompass socializing and relaxing, television watching, and all sports activities such as playing soccer. We add the travel time related to each of the four activities.

We divide the most recent business cycle in the US economy into its three stages of expansion (January 2003-November 2007), crisis and recession (December 2007-June 2009), and recovery (July 2009-December 2010). While unemployment rates have continued to be high after the official end of the recession in June 2009, this periodization recognizes that the Great Recession period was distinct, and a modest recovery in employment was under way, especially in 2010. ${ }^{7}$ Our analysis of ATUS data bears out the qualitative difference in the patterns of employment and labor force participation after June 2009. In order to conduct multiyear analysis that can be generalized to the US population from ATUS data files and that ensures estimate accuracy, we followed the methodology recommended by the BLS, which is

\footnotetext{
${ }^{6}$ We leave out consideration of secondary activities because ATUS provides data on secondary care activities for only children younger than 13 . Our focus on primary care activities enables obtaining results that are generalizable to the US population and sample sizes large enough for robust findings.

${ }^{7}$ This dating of the business cycle does not match the employment changes. While the recession lasted longer and entailed more job losses for men, men began to register job gains in January 2010. For women, the recession started later but as of August 2011 had yet to register job gains (IWPR 2011b).
} 
outlined in the Appendix. This methodology involves appropriate weighting of samples and is the basis for all statistical analysis reported in the paper.

\section{Changes in Women's and Men’s Employment over the Business Cycle}

Our empirical analysis begins with an examination of ATUS data for the changes in women's and men's labor force participation, employment status, and paid work hours over the 2003-10 business cycle. Table 1 shows that between 2003 and 2010 mothers' and fathers' distribution across employment categories became more similar. During the recession, this convergence was driven primarily by the entry of women into the labor force as full-time workers and to a lesser extent by the opposite changes — an exit pattern — for men. The increase in mothers' labor force participation rate during the recession is consistent with the long-term trend of increasing labor force participation rate of women in the US and the entry of women into the labor force as added workers to supplement family income during previous recessions (Şahin, Song, and Hobijn 2010).

Mothers' labor force participation rate increased by 3.6 percentage points during the recession, 2.7 percentage point of which took the form of an increase in the proportion of fulltime employed women. During the recession, fathers' unemployment increased, but by less than the increase in mothers' unemployment. However, unlike mothers, fathers moved into unemployment from full-time jobs. During the recession, the proportion of full-time workers among fathers declined by 1 percentage point. While most of this group of fathers became unemployed, a smaller share of them either found part-time employment or dropped out of the labor force.

Table 1 Women's and men's distribution by employment status over the 2003-10 business cycle (percent)

\begin{tabular}{|c|c|c|c|c|c|c|c|c|c|}
\hline & \multicolumn{3}{|c|}{ Total } & \multicolumn{3}{|c|}{ Women } & \multicolumn{3}{|c|}{ Men } \\
\hline & $\begin{array}{l}\text { Pre } \\
\text { recession } \\
\text { (I) }\end{array}$ & $\begin{array}{l}\text { Recession } \\
\text { (II) }\end{array}$ & $\begin{array}{l}\text { Post } \\
\text { recession } \\
\text { (III) }\end{array}$ & (I) & (II) & (III) & (I) & (II) & (III) \\
\hline Full-time & 65.3 & 66.2 & 63.2 & 44.0 & 46.7 & 45.5 & 89.3 & 88.3 & 83.1 \\
\hline Part-time & 11.2 & 11.4 & 11.6 & 18.9 & 18.8 & 18.2 & 2.6 & 2.9 & 4.2 \\
\hline Unemployed & 3.5 & 4.3 & 6.4 & 3.9 & 4.9 & 6.0 & 3.0 & 3.6 & 6.9 \\
\hline $\begin{array}{l}\text { Out of the } \\
\text { labor force }\end{array}$ & 20.0 & 18.2 & 18.8 & 33.2 & 29.6 & 30.3 & 5.1 & 5.3 & 5.8 \\
\hline
\end{tabular}

Source: Authors' calculations from ATUS data files 2003-10. The numbers are weighted averages of weekend and weekday samples. 
After the recession, there were reversals in mothers' employment status: The proportion of employed mothers declined (by 1.2 percentage points for full-time employed women and 0.6 percentage points for part-time employed women). Mothers became unemployed and moved out of the labor force, contributing to a 1.1 and 0.7 percentage points increase in these groups, respectively. Despite the declines in women's labor force participation and employment, however, the convergence in women's and men's employment status continued, largely because the changes for men during the Great Recession became more pronounced in its aftermath as the proportion of unemployed men nearly doubled. This dramatic increase in unemployment was accompanied by a notable drop in the proportion of men who were employed full-time. The increase in men's unemployment during the postrecession period reflects continued job losses until the end of 2009, after the official end of the recession in June 2009. As data for 2011 become available, these employment status changes in the postrecession period might reflect the slow recovery that has been underway since the beginning of 2010 .

As for hours at paid work, the recession occasioned a convergence similar to that in employment status as mothers' paid work hours increased and fathers' hours declined (Table 2). After the recession, the decline in hours continued, particulary among part-time employed fathers. Paid work hours of mothers with full-time jobs declined slightly while the hours of parttime employed mothers remained unchanged.

Table 2 Weekly hours of full-time and part-time paid work by gender and business cycle (hours)

\begin{tabular}{l|lcc}
\hline \multicolumn{2}{l}{} & Women & Men \\
\hline Full-time employed & Prerecession & 36.2 & 41.7 \\
& Recession & 37.2 & 41.2 \\
& Postrecession & 36.6 & 41.1 \\
\hline Part-time employed & Prerecession & 20.8 & 32.1 \\
& Recession & 21.9 & 31.6 \\
& Postrecession & 21.9 & 25.2 \\
\hline
\end{tabular}

Notes: Authors' calculations from ATUS data files 200310. Women and men are categorized as full-time employed, if they worked at least 35 hours per week.

Overall, these findings show that mothers' and fathers' distribution across employment categories and work hours became more similar over the business cycle. During the recession, this convergence was driven primarily by increases in mothers' labor force participation rate 
rather than disproportionate job losses for fathers. After the recession, the convergence continued even as mothers dropped out of the labor force, primarily because fathers' unemployment increased.

\section{Changes in Time Use over the Business Cycle}

How have these employment distribution and hours changes affected mothers' and fathers' unpaid work, leisure, and personal care hours? Specifically, was there a statistically significant difference in average time spent on different household activities by gender and/or the 2003-10 business cycle, and if so, how important were these changes? The linkages between time use, employment status, and paid work hours come from a rather intuitive trade-off: Employment and increase in paid work hours impose (intensify) time constraints while relaxing income constraints that individuals and their households face in provisioning goods and services to meet their needs. Conversely, unemployment and reductions in paid work hours intensify (introduce) income-constraints and relax time constraints. The gender difference in how individuals react to these constraints, in turn, depends on gendered patterns of time use, such as the disproportionate share of women in unpaid labor and their historical role as primary care givers.

Table 3 reports the results of the analysis of the variance (ANOVA) we conducted to determine whether there was statistically significant variation in time use over the 2003-10 business cycle. The standard F-test indicates such statistically significant variation. We conduct a post-hoc analysis based on the mean hours reported in Table 3 in order to identify the source of this variation: whether it is due to change in time spent by women and men over the business cycle and/or whether there is a gender difference in each stage of the business cycle. 
Table 3 ANOVA Results for daily time use differences by gender and business cycle (hours)

\begin{tabular}{|c|c|c|c|c|c|c|}
\hline & \multicolumn{3}{|c|}{ Men } & \multicolumn{3}{|c|}{ Women } \\
\hline & Prerecession & Recession & Postrecession & Prerecession & Recession & Postrecession \\
\hline \multicolumn{7}{|c|}{ Paid work } \\
\hline & 5.36 & 5.14 & & 2.74 & 3.02 & 2.84 \\
\hline & $(0.00)$ & $(0.009)$ & $(0.010)$ & $(0.004)$ & $(0.008)$ & (0.008) \\
\hline F-value & $1,150,081$ & & & & & \\
\hline \multicolumn{7}{|c|}{ Housework } \\
\hline & 1.43 & 1.40 & 1.49 & 2.85 & 2.66 & 2.75 \\
\hline & $(0.002)$ & $(0.004)$ & $(0.004)$ & $(0.003)$ & $(0.005)$ & $(0.005)$ \\
\hline F-value & $1,333,697$ & & & & & \\
\hline \multicolumn{7}{|c|}{ Childcare } \\
\hline & 0.96 & 1.10 & 1.04 & 2.06 & 2.02 & 2.08 \\
\hline & $(0.002)$ & $(0.004)$ & $(0.003)$ & $(0.002)$ & $(0.004)$ & $(0.004)$ \\
\hline F-value & $1,119,743$ & & & & & \\
\hline \multicolumn{7}{|c|}{ Adultcare } \\
\hline & 0.16 & 0.14 & 0.17 & 0.15 & 0.13 & 0.14 \\
\hline & $(0.001)$ & $(0.001)$ & $(0.002)$ & $(0.001)$ & $(0.001)$ & $(0.001)$ \\
\hline F-value & 3,805 & & & & & \\
\hline \multicolumn{7}{|c|}{ Shopping } \\
\hline & 0.66 & 0.61 & 0.59 & 1.02 & 0.92 & 0.92 \\
\hline & $(0.001)$ & $(0.002)$ & $(0.002)$ & $(0.001)$ & $(0.003)$ & $(0.003)$ \\
\hline F-value & 296,596 & & & & & \\
\hline \multicolumn{7}{|c|}{ Leisure } \\
\hline & 4.24 & 4.30 & 4.44 & 3.79 & 3.78 & 3.69 \\
\hline & $(0.003)$ & $(0.006)$ & $(0.008)$ & $(0.003)$ & $(0.005)$ & $(0.005)$ \\
\hline F-value & 116,637 & & & & & \\
\hline \multicolumn{7}{|c|}{ Personal care } \\
\hline & 8.78 & 8.82 & 8.85 & 9.28 & 9.22 & 9.26 \\
\hline & $(0.002)$ & $(0.004)$ & $(0.005)$ & $(0.002)$ & $(0.004)$ & $(0.004)$ \\
\hline F-value & 193,490 & & & & & \\
\hline $\begin{array}{l}\text { Number of } \\
\text { observations }\end{array}$ & 7,762 & 2,170 & 2,059 & 8,703 & 2,422 & 7,762 \\
\hline
\end{tabular}

Source: Authors' calculations from ATUS 2003-10 data files.

Notes: Standard errors are in parentheses. For each activity, the F-value indicates variation by gender and/or time period that is statistically significant at the 1 percent level. 
Table 4 Analysis of pairwise statistical significance by activity, gender, and phase of business cycle

\begin{tabular}{|c|c|c|c|c|c|c|c|}
\hline & & $\begin{array}{c}\text { Mean } \\
\text { difference }\end{array}$ & $\begin{array}{l}99 \% \mathrm{CI} \text { of } \\
\text { difference }\end{array}$ & $\mathrm{t}$ & $\begin{array}{c}\text { Mean } \\
\text { difference }\end{array}$ & $\begin{array}{l}99 \% \text { CI of } \\
\text { difference }\end{array}$ & $\mathrm{T}$ \\
\hline & & & Paid Work & & & Childcare & \\
\hline \multirow{3}{*}{$\sum^{\bar{E}}$} & Recession v. Prerecession & -0.21 & $-0.22--0.20$ & 106.9 & 0.15 & $0.14-0.15$ & 169.2 \\
\hline & Recession v. Postrecession & 0.31 & $0.30-0.32$ & 123.4 & 0.06 & $0.06-0.07$ & 56.3 \\
\hline & Prerecession v. Postrecession & 0.52 & $0.51-0.52$ & 257.9 & -0.09 & $-0.09--0.08$ & 95.9 \\
\hline \multirow{3}{*}{ 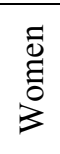 } & Recession v. Prerecession & 0.28 & $0.27-0.29$ & 149.6 & -0.04 & $-0.04--0.03$ & 42.6 \\
\hline & Recession v. Postrecession & 0.18 & $0.17-0.19$ & 76.1 & -0.05 & $-0.06--0.05$ & 51.9 \\
\hline & Prerecession v. Postrecession & -0.1 & $-0.11--0.09$ & 52.3 & -0.02 & $-0.02--0.02$ & 22.7 \\
\hline \multirow{4}{*}{$\begin{array}{l}\dot{\vec{E}} \\
\dot{\vec{e}}\end{array}$} & Recession, Men v. Women & 2.12 & $2.11-2.13$ & 888.1 & -0.92 & $-0.93--0.92$ & 872.1 \\
\hline & Prerecession, Men v. Women & 2.61 & $2.61-2.62$ & 2067.9 & -1.10 & $-1.11--1.10$ & 1977.0 \\
\hline & Postrecession, Men v. Women & 2.00 & $1.99-2.00$ & 814.2 & -1.04 & $-1.04--1.03$ & 957.9 \\
\hline & & & Adult care & & & Housework & \\
\hline \multirow{3}{*}{$\sum_{\Sigma}^{\Xi}$} & Recession v. Prerecession & -0.02 & $-0.02--0.02$ & 74.3 & -0.03 & $-0.04--0.03$ & 30.2 \\
\hline & Recession v. Postrecession & -0.03 & $-0.03--0.03$ & 77.3 & -0.10 & $-0.10--0.09$ & 74.7 \\
\hline & Prerecession v. Postrecession & -0.01 & $-0.01--0.01$ & 23.1 & -0.07 & $-0.07--0.06$ & 63.1 \\
\hline \multirow{3}{*}{ 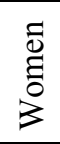 } & Recession v. Prerecession & -0.02 & $-0.02--0.02$ & 60.7 & -0.19 & $-0.19--0.18$ & 193.9 \\
\hline & Recession v. Postrecession & -0.01 & $-0.01--0.01$ & 25.4 & -0.09 & $-0.10--0.09$ & 75.8 \\
\hline & Prerecession v. Postrecession & 0.01 & $0.01-0.01$ & 28.0 & 0.10 & $0.09-0.10$ & 96.2 \\
\hline \multirow{4}{*}{ 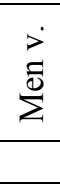 } & Recession & 0.01 & $0.01-0.01$ & 19.4 & -1.26 & $-1.27--1.26$ & 1013.0 \\
\hline & Prerecession & 0.01 & $0.01-0.01$ & 63.0 & -1.42 & $-1.42--1.42$ & 2156.2 \\
\hline & Postrecession & 0.03 & $0.03-0.03$ & 73.1 & -1.26 & $-1.27--1.26$ & 985.3 \\
\hline & & & Shopping & & & isure \& Sports & \\
\hline \multirow{3}{*}{$\sum^{0}$} & Recession v. Prerecession & -0.05 & $-0.06--0.05$ & 95.0 & 0.06 & $0.06-0.07$ & 48.2 \\
\hline & Recession v. Postrecession & 0.02 & $0.01-0.02$ & 21.2 & -0.14 & $-0.14--0.13$ & 80.9 \\
\hline & Prerecession v. Postrecession & 0.07 & $0.07-0.07$ & 119.5 & -0.20 & $-0.21--0.20$ & 147.7 \\
\hline \multirow{3}{*}{$\begin{array}{l}\tilde{\Xi} \\
\text { है } \\
\dot{3}\end{array}$} & Recession v. Prerecession & -0.1 & $-0.10--0.10$ & 193.3 & -0.01 & $-0.02--0.01$ & 10.4 \\
\hline & Recession v. Postrecession & 0.0 & $-0.01--0.00$ & 6.0 & 0.10 & $0.09-0.10$ & 59.8 \\
\hline & Prerecession v. Postrecession & 0.1 & $0.10-0.10$ & 182.5 & 0.11 & $0.10-0.11$ & 84.5 \\
\hline \multirow{3}{*}{$\dot{\vec{E}}$} & Recession & -0.31 & $-0.31--0.30$ & 452.3 & 0.52 & $0.52-0.53$ & 322.6 \\
\hline & Prerecession & -0.36 & $-0.36--0.36$ & 993.0 & 0.44 & $0.44-0.45$ & 520.6 \\
\hline & A Postrecession & -0.33 & $-0.33--0.32$ & 468.6 & 0.75 & $0.75-0.76$ & 454.3 \\
\hline \multirow{4}{*}{$\sum^{\tilde{E}}$} & & & ersonal care & & & & \\
\hline & Recession v. Prerecession & 0.04 & $0.04-0.04$ & 43.1 & & & \\
\hline & Recession v. Postrecession & -0.03 & $-0.03--0.03$ & 25.5 & & & \\
\hline & Prerecession v. Postrecession & -0.07 & $-0.07--0.07$ & 73.9 & & & \\
\hline \multirow{3}{*}{ 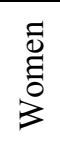 } & Recession v. Prerecession & -0.07 & $-0.07--0.06$ & 74.0 & & & \\
\hline & Recession v. Postrecession & -0.05 & $-0.05--0.04$ & 40.5 & & & \\
\hline & Prerecession v. Postrecession & 0.02 & $0.02-0.02$ & 22.4 & & & \\
\hline \multirow{3}{*}{$\begin{array}{l}\dot{\vec{E}} \\
\dot{E} \\
\dot{\Sigma}\end{array}$} & Recession & -0.4 & $-0.40--0.40$ & 353.0 & & & \\
\hline & Prerecession & -0.5 & $-0.51--0.50$ & 844.3 & & & \\
\hline & Postrecession & -0.37 & $-0.37--0.37$ & 318.6 & & & \\
\hline
\end{tabular}

Source: Authors' calculations from 2003-10 ATUS data files.

Notes: All pairwise mean differences are statistically significant at the 1 percent level. See Table 4 for sample sizes. 
To illustrate the economic significance of these findings, we discuss weekly results, which we report in Table 5 by converting the daily hours presented in Table 4 into weekly hours. ${ }^{8}$ Table 5 reports hours spent on total work (the sum of paid work and unpaid work hours); unpaid work (the sum of childcare, adult care, housework, and shopping); and the nonwork activities of leisure and personal care. Prior to the recession, women's total workload exceeded men's workload. Over the 2003-10 business cycle the total weekly work hours of both women and men declined, but men's hours declined more than women's hours, widening the gap in workload per week from 1.9 hours to 4.1 hours.

Focusing on the changes during the Great Recession, our results show that the gender difference in both paid and unpaid work hours narrowed considerably and by nearly the same amount (2.6 hours and 2.4 hours, respectively). Prior to the recession men performed 18.3 hours more paid work per week than women. During the recession this difference declined to 15.7 hours. The convergence in paid work hours was driven by increase in women's hours at paid work and decline in men's paid work hours during the Great Recession. The convergence in women's and men's unpaid work hours, on the other hand, was driven solely by decline in women's unpaid work hours. Men's unpaid work hours remained the same during the Great Recession. The composition of men's unpaid work changed considerably, however. During the recession, men shifted their unpaid work time away from housework, shopping, and to a lesser extent adult care, toward childcare. With fewer paid work hours and no change in unpaid work hours, men's leisure and personal care time increased slightly during the recession. Women's leisure and personal care time, on the other hand, decreased.

\footnotetext{
${ }^{8}$ We calculate weekly values as the weighted sum of weekend and weekday values as follows: Daily time use for each activity is calculated separately for weekdays and weekends. We then multiply weekend values by two and weekday values by five and sum up the two to obtain the weekly hours spent on each activity. We weight observations by ATUS sample weights.
} 
Table 5 Time spent on paid and unpaid work, leisure, and personal care per week by gender and business cycle (hours)

\begin{tabular}{|c|c|c|c|c|c|c|}
\hline & $\begin{array}{c}\text { Prerecession } \\
\text { (I) }\end{array}$ & $\begin{array}{c}\text { Recession } \\
\text { (II) }\end{array}$ & $\begin{array}{c}\text { Postrecession } \\
\text { (III) }\end{array}$ & (II)-(I) & (III)-(II) & (III)-(I) \\
\hline \multicolumn{7}{|c|}{ Total work $^{\mathrm{a}}$} \\
\hline Women & 61.9 & 61.6 & 61.4 & -0.3 & -0.2 & -0.5 \\
\hline Men & 60.0 & 59.5 & 57.3 & -0.5 & -2.2 & -2.7 \\
\hline Women - Men & 1.9 & 2.1 & 4.1 & 0.2 & 2.0 & 2.2 \\
\hline \multicolumn{7}{|c|}{ Paid work } \\
\hline Women & 19.4 & 21.5 & 20.2 & 2.1 & -1.3 & 0.8 \\
\hline Men & 37.7 & 37.2 & 34.3 & -0.5 & -2.9 & -3.4 \\
\hline Women - Men & -18.3 & -15.7 & -14.1 & 2.6 & 1.6 & 4.2 \\
\hline \multicolumn{7}{|c|}{ Unpaid work $^{\mathrm{b}}$} \\
\hline Women & 42.5 & 40.1 & 41.2 & -2.4 & 1.1 & -1.3 \\
\hline Men & 22.3 & 22.3 & 23.0 & 0.0 & 0.7 & 0.7 \\
\hline Women - Men & 20.2 & 17.8 & 18.2 & -2.4 & 0.4 & -2.0 \\
\hline \multicolumn{7}{|c|}{ Care work and Housework ${ }^{\mathrm{c}}$} \\
\hline Women & 35.4 & 33.7 & 34.8 & -1.7 & 1.1 & -0.6 \\
\hline Men & 17.7 & 18.1 & 18.9 & 0.4 & 0.8 & 1.2 \\
\hline Women - Men & 17.7 & 15.6 & 15.9 & -2.1 & 0.3 & -1.8 \\
\hline \multicolumn{7}{|c|}{ Housework } \\
\hline Women & 19.9 & 18.6 & 19.2 & -1.3 & 0.6 & -0.7 \\
\hline Men & 9.9 & 9.5 & 10.4 & -0.4 & 0.9 & 0.5 \\
\hline Women - Men & 10.0 & 9.1 & 8.8 & -0.9 & -0.3 & -1.2 \\
\hline \multicolumn{7}{|c|}{ Childcare } \\
\hline Women & 14.5 & 14.2 & 14.6 & -0.3 & 0.4 & 0.1 \\
\hline Men & 6.7 & 7.7 & 7.3 & 1.0 & -0.4 & 0.6 \\
\hline Women - Men & 7.8 & 6.5 & 7.3 & -1.3 & 0.8 & -0.5 \\
\hline \multicolumn{7}{|c|}{ Adult care } \\
\hline Women & 1.0 & 0.9 & 1.0 & -0.1 & 0.1 & 0.0 \\
\hline Men & 1.1 & 0.9 & 1.2 & -0.2 & 0.3 & 0.1 \\
\hline Women - Men & -0.1 & 0.0 & -0.2 & 0.1 & -0.2 & -0.1 \\
\hline \multicolumn{7}{|c|}{ Shopping } \\
\hline Women & 7.1 & 6.4 & 6.4 & -0.8 & 0.1 & -0.7 \\
\hline Men & 4.6 & 4.2 & 4.1 & -0.4 & -0.1 & -0.5 \\
\hline Women - Men & 2.5 & 2.2 & 2.3 & -0.4 & 0.1 & -0.2 \\
\hline \multicolumn{7}{|c|}{ Leisure } \\
\hline Women & 26.4 & 26.3 & 25.6 & -0.2 & -0.7 & -0.9 \\
\hline Men & 29.5 & 29.6 & 30.8 & 0.1 & 1.2 & 1.3 \\
\hline Women - Men & -3.1 & -3.3 & -5.3 & -0.3 & -1.9 & -2.2 \\
\hline \multicolumn{7}{|c|}{ Personal care } \\
\hline Women & 64.8 & 64.4 & 64.8 & -0.4 & 0.4 & 0.0 \\
\hline Men & 61.3 & 61.5 & 61.9 & 0.2 & 0.5 & 0.6 \\
\hline Women - Men & 3.5 & 2.9 & 2.9 & -0.5 & -0.1 & -0.6 \\
\hline
\end{tabular}

Source: Authors' calculations from 2003-10 ATUS data files. For results representative of the US population, all observations are weighted by the ATUS sampling weights.

${ }^{\mathrm{a}}$ Total work is the sum of paid work and unpaid work.

${ }^{\mathrm{b}}$ Unpaid work is the sum of time spent on housework, childcare, adult care, and shopping.

${ }^{\mathrm{c}}$ Time spent on childcare, adult care, and housework.

Overall, these findings suggest that women were able to maintain almost as many total work hours per week during the recession as before. They increased their paid work hours by 
reducing both their unpaid work and their personal care and leisure hours. Most of the increase in their paid work hours (2.1 hours) seems to have come from reduction in time spent on housework (1.7 hours) and to a lesser extent shopping time (0.8 hours). Women reduced their childcare hours slightly (from 14.5 to 14.2 hours per week) while men increased their childcare hours by an hour (from 6.7 to 7.7 hours). The changes in the gender composition of childcare during the Great Recession, namely the increase in fathers' hours of childcare time while mothers reduced their hours slightly, are consistent with findings of Morrill and Pabilonia (2011) for 2003-09 and confirm that these patterns held through 2010.

After the recession, convergence in women's and men's paid work hours continued as men's paid work hours declined more than the decline for women. Women reallocated their paid work hours to unpaid work, leaving their total work burden unchanged compared to the Great Recession. The gender difference in unpaid work hours widened, as men increased their unpaid work time less than women during the recovery. Thus, the progress toward a more genderequitable distribution of unpaid work during the recession was reversed during recovery.

The widening gender difference in unpaid work after the recession was driven by larger increases in women's unpaid work time, with women picking up the decline in childcare hours of men as well as increasing their housework hours. As was the case during the Great Recession, men whose paid work hours declined (by 2.9 hours) disproportionately allocated their nonmarket time to having more leisure and to a lesser extent to unpaid household labor and sleeping. Thus, the widening of the gender gap in leisure time continued during recovery. Gender difference in personal care time remained the same as women and men slightly increased their personal care time after the recession. Combined with the findings for unpaid labor, our results suggest that, the paid-unpaid work trade-off is stronger for women than men. During the recession, women whose paid work hours increased financed this increase by sleeping less, having less leisure, and performing less unpaid labor. Men, who spent fewer hours at paid work, spent more time taking care of their children, but they also slept a bit more and had slightly more leisure. In the postrecession period, when the decline in men's paid work hours accelerated, men seem to have allocated a disproportionate share of the reduction in these hours to more leisure and more sleep. Hence, decline in paid work hours, due to unemployment for example, seems to reduce men's overall work burden but alleviates women's overall work burden only slightly. 
These findings suggest that the longstanding macroeconomic question of the extent to which home production substitutes for previously purchased goods and services during recessions also requires a gender-disaggregated analysis. The market versus home provisioning trade-off seems to hold for women but not for men. Similarly, gender-differentiated analysis of time use shows that the welfare effects of business cycles - i.e. the effects on leisure and personal care - vary between women and men.

\section{Gender Segregation in Housework and Childcare}

These gender asymmetric findings on the relationship between paid and unpaid work and the changes in gender differences in time use over the business cycle are likely to be driven by rigidities in the gender-segregated nature of housework and childcare. We present the weekly hours women and men spent on core housework activities of cooking, kitchen cleanup, doing laundry and housecleaning, and other housework activities in Table 6 . The detailed breakdown of housework activities and the weekly hours women and men spent on each activity are reported in Appendix Table 2. Recent analysis of the 2003-07 ATUS data in the literature has found that women spent more time doing food and drink preparation, cleaning, and laundry and sewing than did men, while men spent more time doing maintenance and repair and lawn and garden care than did women (Krantz-Kent 2009). Our findings presented in Table 6 reflect this gender division of unpaid labor and show that before the recession, core housework tasks accounted for 80 percent of women's housework time. Women spent four times as much time (12 hours more) on these activities per week than men. On other housework activities such as interior and exterior repairs and yardwork, men spent two hours more per week than women. ${ }^{9}$

\footnotetext{
${ }^{9}$ Most (56 percent) of men's time in this category was spent on interior and exterior repairs and yard work (Appendix Table 2.)
} 
Table 6 Weekly hours spent on detailed housework activities by gender and business cycle (hours)

\begin{tabular}{rcccccc}
\hline & \multicolumn{2}{c}{ Prerecession } & \multicolumn{2}{c}{ Recession } & \multicolumn{2}{c}{ Postrecession } \\
\cline { 2 - 7 } & Women & Men & Women & Men & Women & Men \\
\hline Core & 15.7 & 3.9 & 14.6 & 4.2 & 15.5 & 4.6 \\
Other & 3.8 & 5.9 & 3.7 & 5.4 & 3.5 & 5.8 \\
Core (percent) & $80 \%$ & $40 \%$ & $80 \%$ & $44 \%$ & $82 \%$ & $44 \%$ \\
\hline \multicolumn{6}{c}{ Gender difference (Women - Men) } \\
\hline Core & 11.8 & \multicolumn{5}{c}{10.9} \\
Other & -2.1 & 10.4 & \multicolumn{2}{c}{-2.3} & \\
Total & 9.7 & -1.7 & \multicolumn{3}{c}{8.6} \\
\hline
\end{tabular}

Note: Core activities are cooking, kitchen cleanup, doing laundry, and housecleaning, while the rest are Other activities. The list of detailed housework activities is in Appendix Table 2. Activities that only men (or only women) performed are excluded from the analysis since these 100 percent or 0 percent values bias the result. See notes to Appendix Table 2 for a list of excluded activities.

During the recession, women's and men's housework hours converged primarily due to decline in women's core housework hours (by an hour). The time spent on other housework tasks also declined - more for men than women. As women spent less time on core housework tasks and men on other housework tasks during the recession, one would expect housework to have become less gender segregated. We examine whether such decline in segregation occurred by calculating the standard Duncan-Duncan (1955) segregation index. Commonly used to measure gender segregation in paid work, this index measures the extent to which women and men perform different types of housework. It identifies the proportion of men or women who would have to change the types of housework they perform in order to have equal distributions of men and women across housework activities. ${ }^{10}$ We calculate the index for 24 housework activities and separately for the prerecession, recession, and postrecession periods to identify the impact of the business cycle on gender segregation in housework.

We find that before the recession, 41 percent of women and/or men would have had to perform different types of housework to achieve an "integrated unpaid housework workforce." This figure decreased to 36 percent during the recession. Most of the decline (72 percent) was

\footnotetext{
${ }^{10}$ The index is defined as $S_{t}=(0.5) \sum_{i}\left|m_{i t}-f_{i t}\right|$ where, $m_{i t}$ and $f_{i t}$ are the proportions of men and women performing task $i$ at time $t$, respectively.
} 
due to convergence in women's and men's time spent on core housework tasks. ${ }^{11}$ These changes suggest that as women faced increasing time constraint they decreased the time they spent on core housework tasks. As Table 6 shows, men, whose paid work hours declined, picked up some of the core housework tasks while reducing their time on other housework activities. These changes are consistent with historical trends in the US, and the latest business cycle simply reinforces the trend.

After the official end of the US recession, however, women and men increased their hours in their respective spheres: women in core housework tasks and men in other housework activities. As Table 6 shows, women increased their time in core housework activities by almost an hour per week, which brought the time women spent on these activities close to its prerecession level. Men increased their time in both core and other housework tasks, but by less than half an hour per week. As a result, the segregation index increased slightly to 37 percent after the recession, which suggests that any gender egalitarian effect of the Great Recession on housework (and the gender norms that underlie it) was shortlived. That said, over the 2003-10 period the movement was toward a more gender-equitable sharing of housework as men continued to slightly increase their time in core housework activities and women slightly decreased their time in other housework activities during the recovery.

Focusing on childcare we see a more equitable sharing of work than in housework. Table 7 presents weekly hours mothers and fathers spent on routine and enriching childcare activities. Routine childcare activities are core tasks of providing physical care to children, while enriching activities encompass educational activities. A detailed list of both forms of childcare is provided in Appendix Table 3.

\footnotetext{
${ }^{11}$ The change in the gender segregation in housework over time may be caused by either women and/or men performing different tasks overtime or change in the total time spent on different tasks. For instance, segregation would decline if women and/or men performed less of their traditional tasks. Alternatively, segregation would decline if more equitably shared tasks were performed more than the highly gender-typed ones. We decompose the index into its two components to reflect these two effects, namely the sex composition effect and the task mix effect to identify the relative contribution of each effect to changes in gender segregation in housework over the business cycle. We find that the sex composition of tasks accounted for 72 percent of the reduction in segregation during the recession.
} 
Table 7 Weekly hours spent on routine and enriching childcare activities by gender and business cycle (hours)

\begin{tabular}{lcccccc}
\hline & Prerecession & \multicolumn{2}{c}{ Recession } & \multicolumn{2}{c}{ Postrecession } \\
\hline & Women & Men & Women & Men & Women & Men \\
\hline Routine & 6.9 & 2.52 & 6.95 & 3.11 & 6.71 & 2.74 \\
Enriching & 4.99 & 3.1 & 4.5 & 3.47 & 5.24 & 3.37 \\
\hline Gender difference (Women - Men) & & & \\
\hline Routine & 4.38 & 3.84 & 3.97 & \\
Enriching & 1.89 & 1.03 & 1.87 & \\
\hline
\end{tabular}

Source: Authors' calculations from 2003-10 ATUS data files. Note: Routine activities comprise of physical care, and all other childcare activities are enriching ones. The list of detailed childcare activities is in Appendix Table 3. Activities that only men (or only women) performed are excluded from the analysis since these 100 percent or 0 percent values bias the results. See notes to Appendix Table 3 for a list of excluded activities.

Several results stand out in Table 7. Before the recession, mothers spent the majority of their childcare hours on routine childcare, while enriching activities accounted for the majority of fathers' childcare time. Mothers spent more than twice as much time as fathers on total childcare per week. The difference was nearly three times as large in routine care (almost 4.5 hours) compared to enriching activities (nearly 2 hours). During the Great Recession, mothers' enriching childcare hours, but not routine childcare hours, declined. Fathers increased their time in routine childcare by an hour and in enriching childcare by 0.37 hours. These findings are consistent with earlier studies on both the trend and the cycle (Bianchi et al. 2000; Morrill and Pabilonia 2011). While mothers may reduce their enriching childcare hours they do not decrease routine childcare hours when they put in more hours at paid work. Fathers compensate by increasing both their routine and enriching childcare hours. Our results show that during the recession these changes led to a convergence in mothers and fathers routine childcare time by about half an hour and enriching childcare hours by nearly an hour ( 0.86 hours) per week.

During recovery, there was a reversal. The gender difference in enriching childcare hours returned to its prerecession level primarily as mothers increased their hours, and fathers slightly decreased their hours. The gender difference in routine hours also widened as fathers decreased their routine childcare hours more than mothers did.

The movement in the Duncan-Duncan index for childcare activities over the business cycle reflects these changes. Before the recession, 16.8 percent of mothers or fathers had to perform different forms of childcare in order to achieve equal sharing of all forms of childcare. 
Considerably smaller compared to the housework segregation index, this figure is consistent with earlier research that childcare constitutes a more gender-equitable ground than housework. During the recession, the index declined to 15.5 percent, reflecting not only the convergence in mothers' and fathers' total childcare hours, but also the convergence in the forms of childcare activities they performed. This convergence stalled after the recession primarily as the enriching childcare hours of mothers and fathers diverged. The segregation index remained nearly constant around 15 percent.

\section{Women's and Men's Time in Unpaid Labor by Employment Status}

In this section, we utilize a formal decomposition technique to examine the extent to which the convergence in the women's and men's employment statuses over the business cycle contributed to the U-pattern in the gender difference in their unpaid labor hours. As our discussion of Table 1 showed, during the recession the convergence in employment status was driven primarily by the entry of women into the labor force as full-time workers, accompanied by the opposite changes for men whose full-time employment and labor force participation declined and part-time employment increased. After the recession, women's labor force participation and employment declined. Despite this reversal for women, the convergence in women's and men's employment status continued after the recession, however, as the changes for men continued at an accelerated rate, notably with the increase in men's unemployment.

Table 8 presents the gender differences in time use over the business cycle by employment status. The underlying time use data by gender, employment status, and phase of business cycle are presented in Appendix Tables 4 and 5. Table 8 shows that, before the recession, gender disparity in all forms of unpaid work was the smallest among full-time workers, followed by the unemployed. The largest differences in childcare and housework hours - the two forms of unpaid labor that accounted for most of women's and men's unpaid labor time - were among those who were out of the labor force. 
Table 8 Gender differences in time use by employment status and business cycle, 2003-10 (hours)

\begin{tabular}{|c|c|c|c|c|c|}
\hline & & Childcare & Adultcare & Housework & Shopping \\
\hline \multirow{4}{*}{ d. } & Full-time & 3.7 & -0.2 & 5.2 & 1.6 \\
\hline & Part-time & 7.5 & -1.0 & 8.5 & 3.3 \\
\hline & Unemployed & 5.4 & -0.4 & 7.1 & 3.8 \\
\hline & $\begin{array}{l}\text { Out of the labor } \\
\text { force }\end{array}$ & 10.5 & -0.4 & 11.4 & 1.7 \\
\hline \multirow{4}{*}{ 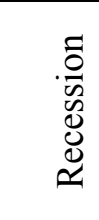 } & Full-time & 2.9 & 0.0 & 4.8 & 1.6 \\
\hline & Part-time & 7.4 & 0.4 & 7.8 & 1.6 \\
\hline & Unemployed & 6.1 & -1.5 & 5.3 & 2.4 \\
\hline & $\begin{array}{l}\text { Out of the labor } \\
\text { force }\end{array}$ & 8.4 & 0.1 & 10.9 & 3.3 \\
\hline \multirow{4}{*}{$\begin{array}{l}\frac{.}{0} \\
\frac{0}{w} \\
0 \\
0 \\
0 \\
0 \\
0 \\
0\end{array}$} & Full-time & 4.1 & 0.0 & $\overline{5.2}$ & 1.6 \\
\hline & Part-time & 2.1 & -0.5 & 7.9 & 2.2 \\
\hline & Unemployed & 6.3 & -1.2 & 4.6 & 1.3 \\
\hline & force & 13.0 & -1.2 & 10.0 & 3.2 \\
\hline
\end{tabular}

Source: Authors' calculations from 2003-10 ATUS data files. All

observations are weighted by ATUS sampling weights.

Notes: gender difference $=$ women's hours - men's hours.

Women and men are categorized as full-time employed, if they worked at least 35 hours per week.

Based on Table 8, Table 9 presents the changes in gender difference in unpaid workload in each employment status category over the business cycle. During the recession, the gender difference in childcare hours decreased among all groups except those who were out of the labor force. Gender disparity in housework hours decreased within each group, and similarly for purchases, with the exception of women and men who were out of the labor force. The gender difference in adult care decreased slightly among all groups except the unemployed. ${ }^{12}$

\footnotetext{
${ }^{12}$ Findings, excluded here for brevity, show that among the employed the gender gap in personal care time decreased while that in leisure increased.
} 
Table 9 Changes in the gender difference in time spent on unpaid labor, personal care, and leisure (hours)

\begin{tabular}{|c|c|c|c|c|c|}
\hline & & Childcare & Adult care & Housework & Shopping \\
\hline \multirow{6}{*}{ 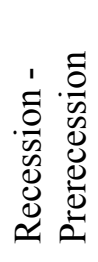 } & Full-time $^{\mathrm{a}}$ & -0.8 & 0.1 & -0.4 & -0.1 \\
\hline & Part-time & -0.1 & 1.3 & -0.7 & -1.7 \\
\hline & Unemployed & 0.7 & -1.1 & -1.9 & -1.5 \\
\hline & Out of the & & & & \\
\hline & labor force & -2.1 & 0.5 & -0.5 & 1.6 \\
\hline & Average $^{\mathrm{b}}$ & -1.3 & 0.0 & -0.9 & -0.4 \\
\hline \multirow{6}{*}{ 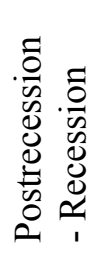 } & Full-time & 1.2 & 0.0 & 0.3 & 0.0 \\
\hline & Part-time & -5.3 & -0.9 & 0.1 & 0.6 \\
\hline & Unemployed & 0.2 & 0.3 & -0.7 & -1.1 \\
\hline & Out of the & & & & \\
\hline & labor force & 4.6 & -1.3 & -0.9 & -0.1 \\
\hline & Average & 0.8 & -0.2 & -0.2 & 0.1 \\
\hline
\end{tabular}

Source: Authors' calculations from 2003-10 ATUS data files. All

observations are weighted by ATUS sampling weights.

Notes: ${ }^{\text {a}}$ Women and men are categorized as full-time employed, if they worked at least 35 hours per week.

${ }^{b}$ Average is the weighted average of the changes in the gender difference in time spent on an activity in each employment category.

By definition, these changes are driven by the changes in women's and men's hours within each employment category and the changes in the distribution of women and men across employment status groups. For instance, all else equal, given the considerably smaller gender difference in unpaid work hours among full-time employed workers, compared to that among women and men who were not in the labor force (Table 8), rise in the proportion of full-time employed in our sample would contribute to a smaller gender disparity in unpaid labor hours. The same effect is expected when there is an increase in the proportion of unemployed in the sample. The reversal of these patterns during the post-Great Recession period, namely, relative increase in the share of women and men who are out of the labor force compared to full-time employed and unemployed workers would contribute to a wider gender gap in unpaid labor. If the recession (or the recovery) affects time use patterns of women and men in each employment category, then these changes would also contribute to the observed changes in time use outcomes in unpaid work.

We apply a standard decomposition technique to the changes in gender differences in unpaid work hours to see whether there is any support for these hypotheses. We focus on the changes in the gender difference in total unpaid workload that followed a U-shaped pattern over the business cycle. Following Juhn, Murphy, and Pierce (1991), and Zveglich and van der Meulen Rodgers (2004), we first partition the gender difference in unpaid labor hours into its 
two components: the gender differentials in time use across the employment categories and gender differentials within each employment category. ${ }^{13}$ Accordingly, the gender difference in unpaid labor hours can be written as

$$
L_{f t}-L_{m t}=\Sigma_{i}\left(\alpha_{f i t} l_{f i t}-\alpha_{m i t} l_{m i t}\right)
$$

where, at time $t(t=$ recession, prerecession, postrecession $), L_{f t}$ and $L_{m t}$ denote women's and men's weekly unpaid labor hours, $l_{f t i}$ and $l_{m t i}$ represent the corresponding unpaid labor hours within employment category $i$ ( $i=$ full-time employed, part-time employed, unemployed, out of the labor force), $\alpha_{f i t}$ is the percentage of women in employment category $i$, and $\alpha_{m i t}$ is the percentage of men in employment category $i$.

With some elementary manipulations, (1) can alternatively be expressed as

$$
L_{f t}-L_{m t}=\Sigma_{i}\left(\alpha_{f i t}-\alpha_{m i t}\right) l_{f i t}+\Sigma_{i} \alpha_{m i t}\left(l_{f i t}-l_{m i t}\right)
$$

The first term on the right-hand side of equation (2) measures the portion of the gender difference in unpaid labor due to variation in women's and men's employment statuses. The second term measures the portion due to women's larger unpaid work hours compared to men within each employment category. Specifically, equation (2) decomposes the unpaid labor difference into these two across- and within-groups components.

Letting $\Delta$ denote the gender difference in any variable, the change in the gender difference in unpaid labor hours between any two periods, $s$ ( $s=$ prerecession, recession) and $t(t$ $=$ recession, postrecession), can be written as follows: ${ }^{14}$

$$
\Delta L_{t}-\Delta L_{s}=\Sigma_{i}\left(\Delta \alpha_{i t}-\Delta \alpha_{i s}\right) l_{m i s}+\Sigma_{i} \alpha_{f i t}\left(\Delta l_{i t}-\Delta l_{i s}\right)
$$

\footnotetext{
${ }^{13}$ Carrington, McCue, and Pierce (1996) and Juhn, Murphy, and Pierce (1991) utilize this method to examine the contribution of the relative changes in public-sector/private-sector wages and employment shares to the trends in the Black/White wage gap and changes in overall wage structure, respectively.

${ }^{14}$ Following Zveglich and van der Meulen Rodgers (2004), the average across prerecession (recession) years is used as the base year, $s$, when comparing the trends to the recession (postrecession) to avoid possible extremes within any given year.
} 
This decomposition breaks down the change in the gender difference in unpaid labor hours over time into two components (that is, between recession and prerecession and between postrecession and recession). The first term on the right-hand side of the equation, acrossgroups effect, captures the contribution of the changes in women's and/or men's employment status between periods. We expect that the increase in the share of employed and unemployed workers in our sample during the recession to have contributed to the observed narrowing of the gender difference in unpaid labor hours during the recession. The reversal of these patterns after June 2009 would have contributed to the widening of the gender disparity in unpaid labor hours. Thus, over the business cycle, we expect this U-pattern in the share of individuals (men and women combined) who were out of the labor force to explain in part the U-pattern in the gender difference in unpaid workload observed over the same period.

The second term, within-groups effect, captures the effect of the changes in gender differences in unpaid labor hours within each employment category. These changes, presented in Table 9, show that the net outcome (weighted average) of the within-group changes was a decline in the gender difference in each type of unpaid labor during the recession. Thus, we expect this component to have contributed to the narrowing of the gender difference in unpaid labor hours during the recession. During recovery, the gender difference in childcare hours and to a lesser extent shopping hours increased while the gender difference in housework and adult care hours decreased slightly. Given the larger magnitudes in childcare and shopping hours, we expect the net outcome of these changes to be widening of the within-groups gap.

Table 10 presents the results of the decomposition of gender differences in weekly unpaid labor hours over the business cycle and the change in these gender differences during the recession and the recovery period. Before the recession, the majority ( 82 percent) of the 19.9 hour gender difference in unpaid labor hours was due to gender differences within employment categories. The remaining 18 percent was due to gender differences across employment categories. During the recession, the within-groups differences explained a larger share (84 percent) of a smaller -17.7 hour- gender difference in unpaid labor. The gender difference increased in the postrecession period to 18.2 hours. The relative contribution of within- and across-group gender differences remained the same.

The last two columns of Table 10 present the percent contribution of the within- and across-group effects to the change in the gender difference in unpaid labor hours during and after the recession. Both changes in women's and men's employment status and the changes in 
gender differences in unpaid labor hours within employment categories contributed to a smaller gender disparity in unpaid workload during the recession, compared to the prerecession period. The within-groups effect — changes in unpaid labor hours within employment categoriesaccounted for the majority (63 percent) of the decline. The remaining 37 percent of the decline was due to the across-groups effect reflecting shifts in women's and men's employment status during the recession. During the recovery period, the within-groups effect accounted for an even larger share (89 percent) of the widening disparity in unpaid workload.

Table 10 Decomposition of gender differences in weekly unpaid labor over the 2003-10 business cycle

\begin{tabular}{rccccc}
\hline & & \multicolumn{3}{c}{ Percent contribution to change } \\
\hline & Prerecession & Recession & Postrecession & $\begin{array}{c}\text { Recession }- \\
\text { Prerecession }\end{array}$ & $\begin{array}{c}\text { Postrecession - } \\
\text { Recession }\end{array}$ \\
\hline $\begin{array}{r}\text { Across-groups } \\
\text { (hours) }\end{array}$ & 3.6 & 2.8 & 2.7 & & \\
(percent) & $18 \%$ & $16 \%$ & $16 \%$ & $37 \%$ & $11 \%$ \\
\hline Within-groups & 16.3 & 14.9 & 15.5 & & \\
$\begin{array}{r}\text { (hours) } \\
\text { (percent) }\end{array}$ & $82 \%$ & $84 \%$ & $84 \%$ & $63 \%$ & $89 \%$ \\
\hline Total & 19.9 & 17.7 & 18.2 & $100 \%$ & $100 \%$ \\
\hline
\end{tabular}

Source: Authors' calculations from 2003-10 ATUS data files. All observations are weighted by ATUS sampling weights.

Notes: Unpaid labor is the sum of housework, childcare, adult care, and shopping hours. See text for the definitions of across- and within-groups components of the gender gap in unpaid labor.

\section{CONCLUSION}

This study examined whether the narrowing gender gap in paid work over the course of the 2003-10 business cycle in the US was mirrored in unpaid work and leisure time. We find that the gender gap in unpaid work followed a U-pattern, narrowing during the Great Recession but widening afterwards. This pattern was driven primarily by gender difference in housework hours, which narrowed during the recession and stalled during recovery. These statistically significant changes were reflected in considerable gendered well-being effects: Before the recession, women's total work hours (paid work, housework, shopping, care work) per week were slightly more than men's hours per week. Over the cycle, this gap widened as men's total work hours per week decreased by 2.7 hours but only by half an hour per week for women. We also find that prior to the recession women had less leisure time than men and their leisure 
shortfall only increased (from 3.1 to 5.3 hours per week) over the cycle as men increased their leisure time and women decreased theirs. In combination, leisure and personal care hours increased for men and declined for women over the cycle.

The Great Recession did not bring about more unpaid labor hours for men. The gender difference in unpaid labor narrowed only because women did less of this work during the recession. This decline in unpaid work was accompanied by the change in employment distribution of women, as they moved into the labor force and, in the main, increased the proportion of full-time employed women. After June 2009, despite a large decline in men's paid work hours (full-time and part-time) and shifts in men's distribution from full-time to part-time employment and unemployment, men's unpaid work hours increased only slightly and by a smaller amount than that of women. This U-shaped pattern in gender differences in unpaid work hours suggests a return to the prerecession division of unpaid labor. Overall, gender inequality in unpaid work has been slower to decline than that in paid work and was accompanied by increase in gender inequality in time spent on leisure.

We sought to identify the underlying processes that contributed to this U-pattern in the gender-segregated nature of housework and childcare activities and in the changes in employment status of women and men. The segregation analysis showed that gender segregation in both activities declined during the Great Recession but the desegregation process stalled in the postrecession period. The decomposition analysis showed that only 37 percent of the narrowing of the gender difference in unpaid labor hours during the recession was due to changes in women's and/or men's employment status. The rest of the decline in gender gap in unpaid work hours was due to more gender-equitable sharing of unpaid labor within employment categories. During the recovery as well, increasing within-group gender gap in unpaid labor hours explained the majority ( 89 percent) of the widening gap. The results of the decomposition analysis suggest that, over and above its employment effects, the Great Recession contributed to more equitable sharing of unpaid work within the household. Future research could examine the impact of the Great Recession on within-household division of labor by focusing on men and women who are matched couples. Convergence in women's and men's paid work hours during the recession creates room for women and men to negotiate a more equitable division of household labor. Examining whether this has been the case during the recession and its aftermath would enhance our understanding of the gendered outcomes of the recession. 
In our sample, the likelihood of unemployment increased after the official end of the recession in June 2009 for both mothers and fathers. Since job losses continued after June 2009 until the end of 2009, in employment terms the recovery period captured in our study is limited to the twelve months in 2010. As ATUS data for 2011 become available, the post-2009 period may reflect job recovery, particularly for men who appear to have registered disproportionate job gains in the recovery according to BLS data. As more data become available, it will be possible to examine the paid labor-unpaid labor nexus, specifically, whether the U-shaped gender difference of unpaid work hours continued. Examination of the impact on single women and men would potentially alter the findings and is also essential to gauge the well-being effects of the recession, especially given the heavier job losses for single women compared to their married counterparts during the recession. For couples, examination of the institutional obstacles to gender-equitable sharing of unpaid labor, including slow changing gender norms, would possibly explain the relatively less gender-equitable sharing of housework compared to childcare and slow progress in both. 


\section{REFERENCES}

Aguiar, Mark, Erik Hurst, and Loukas Karabarbounis. 2011. "Time Use During Recessions." NBER Working Paper No. 17259. Cambridge, MA: National Bureau of Economic Research.

Becker, Gary S. 1965. "A Theory of the Allocation of Time." The Economic Journal 75: 493517.

Benhabib, Jess, Richard Rogerson, and Randall Wright. 1991. "Homework in Macroeconomics: Household Production and Aggregate Fluctuations." Journal of Political Economy 99 (6): 1166-1187.

Bianchi, Suzanne M., John P. Robinson, and Melissa Milkie. 2006. Changing Rhythms of American Family Life. New York: Russell Sage.

Bianchi, Suzanne M., Melissa A. Milkie, Liana C. Sayer, and John P. Robinson. 2000. "Is Anyone Doing the Housework? Trends in the Gender Division of Household Labor." Social Forces 79:191-228.

Bianchi, Suzanne M., Vanessa R. Wight, and Sara B. Raley. 2005. "Maternal Employment and Family Caregiving: Rethinking Time with Children in the ATUS." ATUS Early Results Conference. Bethesda, MD.

Bittman, Michael and Jocelyn Pixley. 1997. The Double Life of the Family. Myth, Hope, and Experience. Sydney: Allen and Unwin.

Blair-Loy, Mary. 2003. Competing Devotions: Career and Family among Women Executives. Cambridge, MA: Harvard University Press.

Blau, Francine D., and Lawrence M. Kahn. 2005. "Changes in the Labor Supply Behavior of Married Women: 1980-2000.” NBER Working Paper No. W11230. Cambridge, MA: National Bureau of Economic Research.

Blau, Francine D. 1998. "Trends in the Well-Being of American Women, 1970-1995." Journal of Economic Literature 36:112-65.

Bureau of Labor Statistics (BLS). 2010. "Employment, Hours, and Earnings from the Current Employment Statistics Survey." US Department of Labor. http://www.bls.gov/news.release/pdf/empsit.pdf (accessed July 24, 2011).

Boushey, Heather. 2011. Changing Places: Women Continue to Lose Jobs as Economy Grows. Washington, DC: Center for American Progress. Available online at http://www.americanprogress.org/issues/2011/05/changing_places.html (accessed July 30, 2011). 
Boushey, Heather and Ann O'Leary. 2010. Our Working Nation How Working Women Are Reshaping America's Families and Economy and What It Means for Policymakers: A Policy Roadmap. Washington, DC: Center for American Progress. Available online at http://www.americanprogress.org/issues/2010/03/pdf/our_working_nation.pdf (accessed July 24, 2011).

(Eds). 2009. "The Shriver Report: A Woman's Nation Changes Everything: A Study by Maria Shriver and the Center for American Progress." Washington, DC: A Woman's Nation and Center for American Progress. Also available online at http://www.shriverreport.com/awn/index.php (accessed July 24, 2011).

Boye, Katarina. 2009. "Relatively Different? How do Gender Differences in Well-Being Depend on Paid and Unpaid Work in Europe?" Social Indicators Research 93:509-525.

Burda, Michael and Daniel S. Hamermesh. 2010. "Unemployment, Market Work and Household Production.” Economic Letters 107: 131-133.

Carr, Deborah S. 2002. "The Psychological Consequences of Work-Family Trade-Offs for Three Cohorts of Men and Women." Social Psychology Quarterly 65:103-24.

Carrington, William J., Kristin McCue, and Brooks Pierce. 1996. "Black/White Wage Convergence: The Role of Public Sector Wages and Employment." Industrial and Labor Relations Review 49 (3): 456-71.

Coltrane, Scott. 2000. "Research on Household Labor: Modeling and Measuring the Social Embeddedness of Routine Family Work." Journal of Marriage and the Family 62: $1208-1233$.

Connelly, Rachel and Jean Kimmel. 2008. "Spousal Influences on Parents' Non-Market Time Choices." Discussion Paper No. 2894. The Institute for the Study of Labor (IZA).

Gauthier, Anne H., Timothy M. Smeeding, and Frank F. Furstenberg, Jr. 2004. “Are Parents Investing Less Time in Children? Trends in Selected Industrialized Countries." Population and Development Review 30 (4): 647-71.

Glass, J., and T. Fujimoto. 1994. "Housework, Paid Work, and Depression Among Husbands and Wives." Journal of Health and Social Behavior 35: 179-91.

Greenwood, Jeremy and Zvi Hercowitz. 1991. "The Allocation of Capital and Time over the Business Cycle." Journal of Political Economy, 99 (6): 1188-1214.

Hartmann, Heidi, Ashley English, and Jeffrey Hayes. 2010. "Women and Men's Employment and Unemployment in the Great Recession." Institute for Women's Policy Research (IWPR) Publication C373. Available online at http://www.in.gov/icw/files/employment.pdf (accessed August 1, 2011).

Hays, Sharon. 1996. The Cultural Contradictions of Motherhood. New Haven: Yale. University Press. 
Hook, Jennifer L. 2006. "Care in Context: Men’s Unpaid Work in 20 Countries: 1965-2003.” American Sociological Review 71: 639-60.

Howie, Peter, John Wicks, John M. Fitzgerald, Douglas Dalenberg, and Rachel Connelly. 2006. "Mothers' Time Spent in Spent in Care of Her Children and Market Work: a Simultaneous Model with Attitudes as Instruments." Applied Economic Letters 2006, 13 (8): 503-06.

Institute for Women's Policy Research (IWPR). 2011a. “Are Women Now Half the Labor Force? The Truth about Women and Equal Participation in the Labor Force." Working Paper C374. Washington, DC: IWPR. Available online at http://www.iwpr.org/publications/pubs/are-women-now-half-the-labor-force-the-truthabout-women-and-equal-participation-in-the-labor-force/at_download/file (accessed July 24, 2011).

. 2011b. "Job Gap between Women and Men Persists in August." IWPR No. Q008. Available online at http://www.iwpr.org/publications/recent-publications (accessed September 15, 2011)

. 2010. "The Costs and Benefits of Paid Sick Days." Testimony of Robert Drago, Institute for Women's Policy Research, Before the Labor Relations Committee of the Pennsylvania House of Representatives Regarding H.B. 1830, the Healthy Families, Healthy Workplaces Act, August 17, 2010. Available online at http://www.iwpr.org/initiatives/family-leave-paid-sick-days/\#publications (accessed July 24, 2011.)

Jacobs, Jerry A., and Kathleen Gerson. 2004. The Time Divide: Work, Family and Gender Inequality. Cambridge, MA: Harvard University Press.

Juhn, Chinhui, Kevin Murphy, and Brooks Pierce. 1991. "Accounting for the Slowdown in Black-White Wage Convergence." In Marvin Kosters, ed., Workers and Their Wages: Changing Patterns in the United States. Washington, DC: American Enterprise Institute Press.

Juhn, Chinhui and Simon Potter. 2007. "Is There Still an Added Worker Effect?" Federal Reserve Bank of New York. Staff Reports no. 310. December.

Kimmel, Jean and Rachel Connelly. 2007. "Mothers' Time Choices: Caregiving, Leisure, Home Production, and Paid Work." Journal of Human Resources 42 (3): 643-61.

Kochhar, Rakesh. 2011. “Two Years of Economic Recovery: Women Lose Jobs, Men Find Them.” Pew Social \& Demographic Trends Report. Washington, DC: Pew Research Center. Also available online at http://pewsocialtrends.org/files/2011/07/Employmentby-Gender_FINAL_7-6-11.pdf (accessed July 30, 2011).

Krantz-Kent, Rachel. 2009. "Measuring Time Spent in Unpaid Household Work: Results From the American Time Use Survey." Monthly Labor Review 132 (7): 46-59. 
Lee, Jungmin, Daiji Kawaguchi, and Daniel S. Hamermesh. 2011. "The Gift of Time.” The University of Texas at Austin Working Paper.

Lee, Marlene A., and Mark Mather. 2008. “US Labor Force Trends.” Population Bulletin 63 (2).

Levy, Frank. 1995. "Incomes and Income Inequality." In Reynolds Farley, ed., State of the Union: America in the 1990s. New York: Russell Sage Foundation.

Lim, Joseph Y. 2000. "The Effects of the East Asian Crisis on the Employment of Women and Men: The Philippine Case." World Development 28 (7): 1285-306.

Mabsout, Ramzi and Irene van Staveren. 2010. "Disentangling Bargaining Power from Individual and Household Level to Institutions: Evidence on Women's Position in Ethiopia." World Development 38 (5): 783-96.

MacDonald, Martha, Shelley Phipps, and Lynn Lethbridge. 2005. "Taking Its Toll: the Influence of Paid and Unpaid Work on Women's Well-being." Feminist Economics 11(1): 63-94.

MacPhail, Fiona and Xiao-Yuan Dong. 2007. "Women's Market Work and Household Status in Rural China: Evidence from Jiangsu and Shandong in the late 1990s." Feminist Economics 13 (3): 93-124.

Macunovich, Diane J. 2010. "Reversals in the patterns of women's labor supply in the United States, 1977-2009." Monthly Labor Review 133 (11): 16-36.

Morrill, Melinda S., and Sabrina W. Pabilonia. 2011. "What Effects Do Macroeconomic Conditions Have on Families' Time Together?” DPRPD Working Paper. http://www.popcenter.umd.edu/research/sponsored-events/timeuse-2011/iptupapers/Morrill_Pabilonia_Maryland2011.pdf.

Pabilonia, Sabrina Wulff and Younghwan Song. 2011. "Single Mothers' Time Preference, Smoking, and Enriching Childcare: Evidence from Time Diaries." Eastern Economic Journal forthcoming.

Risman, Barbara J. 1998. Gender Vertigo: American Families in Transition. Yale University Press.

Rones, Philip L., Randy E. Ilg, and Jennifer M. Gardner. 1997. "Trends in Hours of Work Since the Mid-1970s." Monthly Labor Review 120: 3-14.

Sandberg, John and Sandra Hofferth. 2001. "Changes in Children's Time with Parent, U. S. 1981-1997.” Demography 38: 423-36.

Sayer, Liana C. 2005. “Gender, Time and Inequality: Trends in Women's and Men's Paid Work, Unpaid Work and Free Time.” Social Forces 84 (1): 285-303. 
Sayer, Liana C., Philip N. Cohen, and Lynne M. Casper. 2004.”Women, Men and Work." The American People Census 2000 Series. New York: Russell Sage and Population Reference Bureau.

Singh, Ajit and Ann Zammit. 2000. "International Capital Flows: Identifying the Gender Dimension.” World Development 28 (7): 1249-1268.

Stewart, Jay. 2010. "The Timing of Maternal Work and Time with Children.” Industrial and Labor Relations Review 64 (1): 181-201.

Şahin, Ayşegul, Joseph Song, and Bart Hobijn. 2010. "The Unemployment Gender Gap During the 2007 Recession." Current Issues in Economics and Finance Federal Reserve Bank of New York 16, no.2.

Thompson, Linda and Alexis J. Walker. 1989. "Gender in Families: Women and Men in Marriage, Work, and Parenthood.” Journal of Marriage and the Family 51: 845-71.

US Census Bureau 2011. American Time Use Survey User's Guide: Understanding ATUS 2003 to 2010 .

US Census Bureau. 2006. "Current Population Survey Design and Methodology." Technical Paper 66.

Williams, Joan. 2000. Unbending Gender: Why Family and Work Conflict and What to Do About It. New York: Oxford University Press.

Zveglich, Joseph E., and Yana van der Meulen Rodgers. 2004. "Occupational Segregation and the Gender Wage Gap in a Dynamic East Asian Economy." Southern Economic Journal 70 (4): pp. 850-75. 


\section{APPENDIX}

\section{Methodology}

In order to obtain unbiased multi-year estimates, the Bureau of Labor Statistics (BLS) advises use of a replicate variance method to generate standard errors that uses subsample (replicate) weights to calculate replicate estimates (US Census Bureau 2011, p. 33). This method generates unbiased estimates that correct for sampling bias as well as nonsampling errors such as response variance and intra-interviewer correlation (US Census Bureau 2006, p. 2). The logic behind the method is that the variability among estimates based on various subsamples of the one actual sample is a good proxy for all the samples. For ATUS, variability among 160 subsamples is used in variance estimation of the samples. In simplest terms, we generate 161 mean estimates of each activity separately for each sample (e.g. daily minutes women on average spent doing housework on an average day before the recession), using the ATUS final sampling weight (that

yields the original estimate) and the 160 subsample weights (that yield the replicate estimates). The deviation of the estimate we generate using the ATUS final sampling weight (the original estimate) from each of the 160 estimates forms the basis for unbiased estimates. The formulas we use to obtain estimates and standard errors are provided by the BLS: We use the following formula to generate the original estimate of daily time use:

$$
\bar{T}_{j}^{P}=\frac{\sum_{i} f w g t_{i} I_{i j} T_{i j}}{\sum_{i} f w g t_{i} I_{i j}}
$$

where $\bar{T}_{i j}$ is the amount of time spent on activity $j$ by respondent $i, f w g t_{i}$ is the final weight for respondent $i$, and $I_{i j}$ is an indicator that equals 1 if respondent $i$ participated in activity $j$ during the reference day and 0 otherwise. The weighted sum of time use divided by the sum of weights results in the average total hours spent per day on an activity.

The deviations between the replicate estimates and this original estimate form the basis of the variance calculation. We use the following formula for calculating standard errors provided by BLS:

$$
\operatorname{Var}\left(\hat{Y}_{O}\right)=\left(\frac{4}{160}\right) \sum_{i=1}^{160}\left(\hat{Y}_{i}-\hat{Y}_{O}\right)^{2}
$$


where $\mathrm{Y}$ is the characteristic of interest (e.g. gender), $\hat{Y}_{O}$ is the original estimate of $\mathrm{Y}$, and $\hat{Y}_{i}$ is the $i^{\text {th }}$ replicate estimate of $Y$. We calculate $\hat{Y}_{i}$ for each record, sum

the 160 squared deviations of the replicate estimates from the original estimate $\hat{Y}_{O}$, and multiply by (4/160) to get the variance. 


\section{Tables}

Appendix Table 1 Characteristics of women and men in the sample, 2003-10

\begin{tabular}{|c|c|c|}
\hline & Women & Men \\
\hline Recession $(1 / 2003-11 / 2007)$ & 19 & 19 \\
\hline Postrecession $(7 / 2009-12 / 2010)$ & 18 & 19 \\
\hline Employed & 62 & 90 \\
\hline Unemployed & 4.5 & 3.7 \\
\hline Spouse is employed & 89 & 63 \\
\hline Age (years) & 38 & 40 \\
\hline Usual hours of work per week (hours) & 22 & 39 \\
\hline Usual hourly earnings (\$) & $\$ 555$ & $\$ 773$ \\
\hline Spouse's usual hours of work per week (hours) & 37 & 22 \\
\hline BA degree or more & 34 & 32 \\
\hline Some college education & 24 & 23 \\
\hline Less than a high-school education & 14 & 15 \\
\hline Metropolitan residence & 67 & 67 \\
\hline Hispanic & 22 & 22 \\
\hline African-American & 8 & 9 \\
\hline \multicolumn{3}{|l|}{ Households $(\mathrm{HH})$ with children: } \\
\hline 1-year-old or younger & 23 & 22 \\
\hline Ages 2-4 & 34 & 35 \\
\hline Ages 5-9 & 54 & 55 \\
\hline Ages $10-14$ & 51 & 50 \\
\hline Ages $15-17$ & 28 & 28 \\
\hline $\mathrm{HH}$ where a third adult is present & 24 & 24 \\
\hline Summer diary & 26 & 25 \\
\hline Weekends or Holidays & 30 & 30 \\
\hline Number of observations & 13,439 & 11,991 \\
\hline
\end{tabular}

Source: Authors' calculations from 2003-10 ATUS data files. All observations are weighted by ATUS sampling weights. Unless otherwise stated, all numbers are percentages. 
Appendix Table 2 Weekly hours spent on detailed housework activities by gender and business cycle

\begin{tabular}{|c|c|c|c|c|c|c|}
\hline & \multicolumn{2}{|c|}{ Prerecession } & \multicolumn{2}{|c|}{ Recession } & \multicolumn{2}{|c|}{ Postrecession } \\
\hline & Women & Men & Women & Men & Women & Men \\
\hline Food and drink preparation & 5.6 & 1.7 & 5.3 & 2.0 & 5.7 & 2.2 \\
\hline Interior cleaning & 5.1 & 1.3 & 4.9 & 1.3 & 5.1 & 1.5 \\
\hline Laundry & 3.0 & 0.4 & 2.6 & 0.4 & 2.7 & 0.5 \\
\hline Kitchen and food clean-up & 2.0 & 0.5 & 1.8 & 0.5 & 2.0 & 0.4 \\
\hline Lawn, garden, \& houseplant care & 0.8 & 1.8 & 0.6 & 1.6 & 0.6 & 1.8 \\
\hline $\begin{array}{l}\text { Household \& personal organization and } \\
\text { planning }\end{array}$ & 0.7 & 0.5 & 0.8 & 0.4 & 0.7 & 0.6 \\
\hline Care for animals and pets & 0.4 & 0.4 & 0.5 & 0.4 & 0.5 & 0.4 \\
\hline Interior arrangement $\&$ repairs & 0.4 & 0.8 & 0.4 & 0.7 & 0.3 & 0.7 \\
\hline Storing interior household items & 0.3 & 0.1 & 0.2 & 0.1 & 0.2 & 0.1 \\
\hline Financial management & 0.2 & 0.2 & 0.2 & 0.1 & 0.2 & 0.1 \\
\hline HH \& personal e-mail \& messages & 0.2 & 0.1 & 0.4 & 0.2 & 0.3 & 0.2 \\
\hline $\begin{array}{l}\text { Sewing, repairing, \& maintaining } \\
\text { textiles }\end{array}$ & 0.2 & 0.003 & 0.1 & 0.001 & 0.1 & 0.001 \\
\hline HH \& personal mail \& messages & 0.1 & 0.1 & 0.1 & 0.1 & 0.1 & 0.03 \\
\hline Food presentation & 0.1 & 0.02 & 0.1 & 0.02 & 0.1 & 0.01 \\
\hline Exterior cleaning & 0.1 & 0.3 & 0.1 & 0.4 & 0.1 & 0.4 \\
\hline $\begin{array}{l}\text { Exterior repair, improvements, \& } \\
\text { decoration }\end{array}$ & 0.1 & 0.4 & 0.1 & 0.3 & 0.1 & 0.4 \\
\hline Vehicle repair and maintenance & 0.1 & 0.7 & 0.04 & 0.6 & 0.1 & 0.6 \\
\hline $\begin{array}{l}\text { Appliance, tool, and toy set-up, repair, } \\
\& \text { maintenance }\end{array}$ & 0.04 & 0.2 & 0.02 & 0.2 & 0.02 & 0.2 \\
\hline Heating and cooling & 0.02 & 0.1 & 0.01 & 0.2 & 0.02 & 0.1 \\
\hline Building and repairing furniture & 0.02 & 0.1 & 0.02 & 0.01 & 0.01 & 0.1 \\
\hline Ponds, pools, and hot tubs & 0.02 & 0.04 & 0.01 & 0.1 & 0.03 & 0.04 \\
\hline Home security & 0.01 & 0.02 & 0.01 & 0.01 & 0.01 & 0.01 \\
\hline Vehicles, n.e.c. & 0.001 & 0.002 & 0.001 & 0.001 & 0.000 & 0.000 \\
\hline Pet and animal care, n.e.c. & 0.000 & 0.000 & 0.001 & 0.000 & 0.004 & 0.03 \\
\hline Number of observations & 8,703 & 7,762 & 2,422 & 2,170 & 2,314 & 2,059 \\
\hline
\end{tabular}

Source: Authors' calculations from 2003-10 ATUS data files. For results representative of the US population, all observations are weighted by the ATUS sampling weights.

Notes: Activities are listed in descending order of time spent by women before the recession.

Activities that are not performed by either women or men are excluded from the analysis. These are "not elsewhere classified" (n.e.c.) activities related to-appliances and tools, lawn and garden, food and drink preparation, presentation and clean-up, housework, interior maintenance, repair and decoration. 
Appendix Table 3 Weekly hours spent on detailed childcare activities by gender and business cycle

\begin{tabular}{lcccccc}
\hline & \multicolumn{2}{c}{ Prerecession } & \multicolumn{2}{c}{ Recession } & \multicolumn{2}{c}{ Postrecession } \\
\hline & Women & Men & Women & Men & Women & Men \\
\hline Physical care & 5.33 & 1.77 & 5.34 & 2.25 & 4.90 & 2.02 \\
Reading to/with & 0.44 & 0.16 & 0.40 & 0.21 & 0.39 & 0.21 \\
Playing, not sports & 2.42 & 1.80 & 2.10 & 2.04 & 2.63 & 2.04 \\
Arts and crafts & 0.04 & 0.00 & 0.02 & 0.00 & 0.02 & 0.01 \\
Playing sports & 0.06 & 0.12 & 0.08 & 0.09 & 0.05 & 0.14 \\
Organization \& planning & 0.11 & 0.02 & 0.15 & 0.05 & 0.15 & 0.04 \\
Looking after & 0.68 & 0.42 & 0.68 & 0.46 & 0.81 & 0.35 \\
Attending events & 0.56 & 0.35 & 0.74 & 0.48 & 0.63 & 0.39 \\
Waiting for/with & 0.18 & 0.06 & 0.15 & 0.07 & 0.22 & 0.09 \\
Picking up/dropping off & 0.51 & 0.21 & 0.55 & 0.23 & 0.56 & 0.23 \\
Talking with/listening - & 0.53 & 0.20 & 0.40 & 0.20 & 0.51 & 0.23 \\
Caring for helping, n.e.c. & 0.09 & 0.05 & 0.02 & 0.01 & 0.05 & 0.02 \\
Homework & 0.85 & 0.42 & 0.74 & 0.44 & 0.96 & 0.33 \\
Meetings \& school conferences & 0.09 & 0.04 & 0.08 & 0.05 & 0.07 & 0.01 \\
Number of observations & 8,703 & 7,762 & 2,422 & 2,170 & 2,314 & 2,059 \\
\hline
\end{tabular}

Source: Authors' calculations from 2003-10 ATUS data files. For results representative of the US population, all observations are weighted by the ATUS sampling weights.

Notes: The activities are listed in a descending order of the time spent by women before the recession. Home schooling of household children and waiting associated with children's education are excluded from the analysis because either women or men do not perform these activities. 
Appendix Table 4 Weekly unpaid labor, personal care, and leisure hours by gender, employment status, and business cycle (2003-10)

\begin{tabular}{|c|c|c|c|c|c|c|c|c|}
\hline & & $\begin{array}{c}\text { Unpaid } \\
\text { work }\end{array}$ & Childcare & $\begin{array}{l}\text { Adult } \\
\text { care }\end{array}$ & Housework & Shopping & $\begin{array}{c}\text { Personal } \\
\text { care }\end{array}$ & Leisure \\
\hline & \multicolumn{8}{|c|}{ Women } \\
\hline \multirow{5}{*}{ 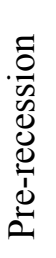 } & Full-time & 31.6 & 10.1 & 0.9 & 14.5 & 6.1 & 63.6 & 21.8 \\
\hline & Part-time & 41.6 & 14.8 & 0.9 & 18.4 & 7.4 & 64.5 & 25.7 \\
\hline & Unemployed & 52.3 & 14.7 & 1.9 & 26.5 & 9.2 & 67 & 34 \\
\hline & $\begin{array}{l}\text { Out of the } \\
\text { labor force }\end{array}$ & 55.4 & 19.8 & 1.2 & 26.6 & 7.8 & 66.5 & 31.6 \\
\hline & Total & 42.5 & 14.5 & 1 & 19.9 & 7.1 & 64.8 & 26.4 \\
\hline \multirow{5}{*}{ 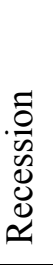 } & Full-time & 30.4 & 10.2 & 0.9 & 13.5 & 5.8 & 62.8 & 22.5 \\
\hline & Part-time & 39 & 14.4 & 0.7 & 18.2 & 5.7 & 65 & 25.4 \\
\hline & Unemployed & 52.2 & 18.1 & 0.7 & 26.2 & 7.2 & 67.6 & 29.8 \\
\hline & $\begin{array}{l}\text { Out of the } \\
\text { labor force }\end{array}$ & 54 & 19.9 & 1.2 & 25.4 & 7.5 & 65.9 & 32.2 \\
\hline & Total & 40.1 & 14.2 & 0.9 & 18.6 & 6.4 & 64.4 & 26.3 \\
\hline \multirow{5}{*}{ 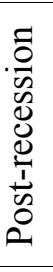 } & Full-time & 31.3 & 10.8 & 0.8 & 14.1 & 5.6 & 63 & 21.1 \\
\hline & Part-time & 39.5 & 13.3 & 0.7 & 18.7 & 6.8 & 64.5 & 25.6 \\
\hline & Unemployed & 50.8 & 16.8 & 1.9 & 25.2 & 6.9 & 68.1 & 30 \\
\hline & $\begin{array}{l}\text { Out of the } \\
\text { labor force }\end{array}$ & 53.9 & 20.2 & 1.1 & 25.4 & 7.2 & 66.2 & 31.2 \\
\hline & Total & 41.3 & 14.6 & 1 & 19.2 & 6.4 & 64.8 & 25.6 \\
\hline & \multicolumn{8}{|c|}{ Men } \\
\hline \multirow{5}{*}{ 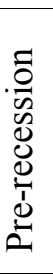 } & Full-time & 21.2 & 6.4 & 1 & 9.3 & 4.5 & 60.5 & 27.5 \\
\hline & Part-time & 23.3 & 7.3 & 1.9 & 9.9 & 4.2 & 62.2 & 33.9 \\
\hline & Unemployed & 36.3 & 9.3 & 2.3 & 19.4 & 5.4 & 66.3 & 43.5 \\
\hline & $\begin{array}{l}\text { Out of the } \\
\text { labor force }\end{array}$ & 32.3 & 9.3 & 1.5 & 15.3 & 6.1 & 70.6 & 50.6 \\
\hline & Total & 22.3 & 6.7 & 1.1 & 9.9 & 4.6 & 61.3 & 29.5 \\
\hline \multirow{5}{*}{ 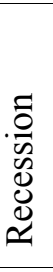 } & Full-time & 21.1 & 7.3 & 0.9 & 8.7 & 4.2 & 61 & 27.5 \\
\hline & Part-time & 21.8 & 7 & 0.3 & 10.4 & 4.1 & 64.9 & 31 \\
\hline & Unemployed & 39.8 & 12 & 2.2 & 20.9 & 4.8 & 60.7 & 41.7 \\
\hline & $\begin{array}{l}\text { Out of the } \\
\text { labor force }\end{array}$ & 31.3 & 11.5 & 1 & 14.5 & 4.2 & 68.6 & 55.2 \\
\hline & Total & 22.4 & 7.7 & 0.9 & 9.5 & 4.2 & 61.5 & 29.6 \\
\hline \multirow{5}{*}{ 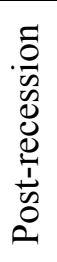 } & Full-time & 20.5 & 6.7 & 0.9 & 8.9 & 4 & 60.6 & 27.8 \\
\hline & Part-time & 27.8 & 11.2 & 1.2 & 10.7 & 4.6 & 66.1 & 33.3 \\
\hline & Unemployed & 39.8 & 10.5 & 3.1 & 20.7 & 5.6 & 64.5 & 40.5 \\
\hline & $\begin{array}{l}\text { Out of the } \\
\text { labor force }\end{array}$ & 28.8 & 7.2 & 2.3 & 15.4 & 4 & 70.3 & 52.9 \\
\hline & Total & 23 & 7.3 & 1.2 & 10.4 & 4.1 & 61.9 & 30.8 \\
\hline
\end{tabular}

Source: Authors' calculations from 2003-10 ATUS data files. For results representative of the US population, all observations are weighted by the ATUS sampling weights.

Notes: Women and men are categorized as full-time employed, if they worked at least 35 hours per week. 
Appendix Table 5 Changes in weekly unpaid labor, personal hours by gender and employment status

\begin{tabular}{|c|c|c|c|c|c|c|c|}
\hline & $\begin{array}{l}\text { Unpaid } \\
\text { work }\end{array}$ & Childcare & $\begin{array}{l}\text { Adult } \\
\text { care }\end{array}$ & Housework & Shopping & $\begin{array}{l}\text { Personal } \\
\text { care }\end{array}$ & Leisure \\
\hline \multicolumn{8}{|l|}{ Women } \\
\hline \multicolumn{8}{|c|}{ Change with the Recession } \\
\hline Full-time & -1.2 & 0.1 & 0 & -1 & -0.3 & -0.8 & 0.7 \\
\hline Part-time & -2.6 & -0.4 & -0.2 & -0.2 & -1.7 & 0.5 & -0.3 \\
\hline Unemployed & -0.1 & 3.4 & -1.2 & -0.3 & -2 & 0.6 & -4.2 \\
\hline $\begin{array}{l}\text { Out of the } \\
\text { labor force }\end{array}$ & -1.4 & 0.1 & 0 & -1.2 & -0.3 & -0.6 & 0.6 \\
\hline \multicolumn{8}{|c|}{ Change with the official end of Recession } \\
\hline Full-time & 0.9 & 0.6 & -0.1 & 0.6 & -0.2 & 0.2 & -1.4 \\
\hline Part-time & 0.5 & -1.1 & 0 & 0.5 & 1.1 & -0.5 & 0.2 \\
\hline Unemployed & -1.4 & -1.3 & 1.2 & -1 & -0.3 & 0.5 & 0.2 \\
\hline $\begin{array}{l}\text { Out of the } \\
\text { labor force }\end{array}$ & -0.1 & 0.3 & -0.1 & 0 & -0.3 & 0.3 & -1 \\
\hline \multicolumn{8}{|l|}{ Men } \\
\hline \multicolumn{8}{|c|}{ Change with the Recession } \\
\hline Full-time & -0.1 & 0.9 & -0.1 & -0.6 & -0.3 & 0.5 & 0 \\
\hline Part-time & -1.5 & -0.3 & -1.6 & 0.5 & -0.1 & 2.7 & -2.9 \\
\hline Unemployed & 3.5 & 2.7 & -0.1 & 1.5 & -0.6 & -5.6 & -1.8 \\
\hline $\begin{array}{l}\text { Out of the } \\
\text { labor force }\end{array}$ & -1 & 2.2 & -0.5 & -0.8 & -1.9 & -2 & 4.6 \\
\hline \multicolumn{8}{|c|}{ Change with the official end of Recession } \\
\hline Full-time & -0.6 & -0.6 & 0 & 0.2 & -0.2 & -0.4 & 0.3 \\
\hline Part-time & 6 & 4.2 & 0.9 & 0.3 & 0.5 & 1.2 & 2.3 \\
\hline Unemployed & 0 & -1.5 & 0.9 & -0.2 & 0.8 & 3.8 & -1.2 \\
\hline $\begin{array}{l}\text { Out of the } \\
\text { labor force }\end{array}$ & -2.5 & -4.3 & 1.3 & 0.9 & -0.2 & 1.7 & -2.3 \\
\hline $\begin{array}{l}\text { Source: Autho } \\
\text { US population } \\
\text { Notes: Womer } \\
\text { hours per wee }\end{array}$ & $\begin{array}{l}\text { calcula } \\
11 \text { obser } \\
\text { nd men }\end{array}$ & $\begin{array}{l}\text { ons from } \\
\text { tions are } \\
\text { e categor }\end{array}$ & ightec & $\begin{array}{l}\text { TUS data fi } \\
\text { the ATUS } \\
\text { time emplo }\end{array}$ & $\begin{array}{l}\text { For result } \\
\text { mpling we } \\
\mathrm{d} \text {, if they }\end{array}$ & $\begin{array}{l}\text { epresentat } \\
\text { ts. }\end{array}$ & $\begin{array}{l}\text { ve of the } \\
35\end{array}$ \\
\hline
\end{tabular}

